\title{
Patterns of leadership and perceived distribution of influence
}

\author{
E.A.Coster \\ Department of Industrial Psychology, University of South Africa, P.O. Box 392, Pretoria, 0001 Republic of South Africa
}

\begin{abstract}
This study investigates the relationship between the perceived distribution of influence and leadership. Research suggests that the distribution of a specific type of influence may be associated with a particular hierarchical level. The results of the present study indicate that differences in the perception of influence exist. Further analysis of the relationship between the hierarchical levels and influence domains showed that the top echelons perceive themselves to have the most influence over all the domains of influence. The results indicate that other variables need to be included to determine the association between leadership and the distribution of influence.
\end{abstract}

Hierdie studie ondersoek die verband tussen die waargenome verspreiding van invloed en leierskap. Navorsing dui daarop dat die verspreiding van 'n spesifieke tipe invloed verband hou met 'n sekere hiërargiese vlak. Die resultate van die huidige studie dui aan dat verskille in die waarneming van invloed bestaan. 'n Verdere ondersoek om die verband tussen hiërargiese vlak en die domeine van invloed te bepaal, dui daarop dat die top vlak ervaar dat hulle die meeste invloed uitoefen oor al die domeine van invloed. Die resultate dui aan dat ander veranderlikes in so ' $n$ ontleding ingesluit moet word om die verband tussen leierskap en die verspreiding van invloed te bepaal.

\section{Introduction}

Leadership is represented by a voluminous body of confusing and conflicting literature. Scott, Mitchell \& Birnbaum (1981) note that this is due to the disagreement of what is meant by the term leadership. Leadership theory has subsequently been characterized by several approaches, each endeavouring to explain what makes it effective.

The earliest view of leadership was based on the trait approach, which postulated that leadership is a function of the personal qualities of the individual. Dissatisfaction with this approach gave way to the behavioural approach which put forward the view that leadership depended on how the person acted or behaved. Among these theories were the Ohio State University and Michigan University studies and the Managerial Grid (Blake and Mouton, 1964). The issue of 'one best way' has more recently given way to a contingency approach. Among these, Fiedler's (1967) model, Hersey \& Blanchard's (1982) situational leadership, House's (1971) path-goal theory and Vroom \& Yetton's (1973) leader participation model, stand out.

Katz \& Kahn (1978) note that the development of the contingency theories has taken cognizance of the organization as a social system. The systems perspective has given rise to the role concept, which is associated with the positions in an organizational hierarchy. The role concept therefore permits the position component of leadership to be scrutinized in terms of its influential impact on the organization. According to Katz \& Kahn (1978) leadership is frequently equated to the exertion of influence tied to the position in the hierarchy. Leadership consequently entails an influencing component which is not randomly distributed throughout the organization, but which is closely associated with a position in terms of the hierarchical principle (Tannenbaum, 1961).

Katz \& Kahn (1978) have distinguished between three types of leader behaviour associated with three hierarchical positions. These are: the origination of structure or policy making, interpolation of structure and use of existing structures. The authors describe these behaviours in terms of the top echelon, intermediate levels (middle management) and lower levels, respectively. Furthermore, each level is characterized by specific cognitive abilities and skills illustrated in Figure 1.

Katz \& Kahn (1978) observe that, although the top level may exercise all three patterns of leadership, skills at one level may be irrelevant at another. This is corroborated by other research (Fiedler, 1967; Vroom, 1976).

From the above exposition of the pattern of leadership, it would appear therefore, that the influential acts of leadership are distributed in different ways (Duncan, 1971). Moch, Cammann \& Cooke (1983) conclude that in the light of previous research (Becker \& Gordon, 1966; Parsons, 1960), organizations are characterized by at least three independent influence domains which are distributed differentially throughout the organization. These domains include, influence over one's own work, influence over resource allocation, and influence over coordination activities.

Work influence is exercised to a large extent at all

\begin{tabular}{lcc}
\hline $\begin{array}{l}\text { Leadership } \\
\text { process }\end{array}$ & $\begin{array}{c}\text { Organizational } \\
\text { level }\end{array}$ & $\begin{array}{c}\text { Cognitive } \\
\text { skills }\end{array}$ \\
\hline
\end{tabular}

Origination: change, creation Top echelons System perspective and elimination of structure

Interpolation of structure Intermediate levels Subsystem perspective

Administration: use of Lower levels Technical existing structures knowledge

Figure 1 Leadership patterns. Adapted from Katz \& Kahn, 1978. 
hierarchical levels, although the top echelon has most control over their work (Moch, et al., 1983). According to Moch, et al. (1983), resource allocation influence and coordination influence cannot be assumed to be of equal importance to the different organizational positions, suggesting therefore, that some influence domains are more appropriate to specific levels of leadership than others, similar to the congruence between the levels of leadership and cognitive and affective skills, described earlier.

The distribution of influence is a relational phenomenon (Hall, 1982). As a result, inconsistencies in the perception of its distribution occur (Moch, et al., 1983). Research (Peabody, 1962) has shown that influence is perceived differently by individuals. This is also demonstrated by Moch, et al. (1983) in reports of the distribution of influence, where interview data indicated respondents' perceptions of the influence wielded by different organizational levels.

Research evidence presented above suggests that the perceived distribution of a specific domain of influence may be associated with a specific level of leadership. A closer examination of this association, suggests that several propositions may be formulated in this respect, based on Katz \& Kahn's patterns of leadership.

\section{Purpose of this study}

The purpose of this study is to examine the following propositions:

(a) The top echelons perceive themselves to exert the most influence over the work influence domain. These hierarchical positions need to have considerable influence over the execution of their tasks, because pressure from the environment and the concomitant uncertainty require them to respond to unusual demands. Freedom and decision making latitude are consequently important at this level to maintain the systemic perspective proposed by Katz \& Kahn (1978). The subordination of structure adds credence to the argument that the top echelon needs to assert their autonomy over the existing structure to achieve the organization's goals (Katz \& Kahn, 1978).

(b) The nature of the tasks at the intermediate levels of leadership suggests that they perceive themselves to have the most influence over the allocation of resources. The primary responsibility of this level is the operationalization of policy. This entails the creation and maintenance of structure to implement policy decisions. According to Katz \& Kahn (1978) the critical task of these incumbents is to optimize organizational functioning through a relevant knowledge of the different subsystems and their relationships with other subsystems. Moch, et al. (1983) note that the activities involve spending large sums of money and changing staff membership through hiring and firing.

(c) The leadership acts at the lowest level suggest that these incumbents perceive themselves to have the most influence over the coordination of activities. At this level, Katz \& Kahn (1978) note that the leadership acts involve using the existing structure to reach the stated objectives. Coordination appears to be of importance in getting the tasks done. They point out that this involves the coordination of work flow, appropriate directives and the proper tools.

\section{Research methodology}

\section{Sample}

The population in this study consisted of 3457 employees in a commercial bank which represents $80 \%$ of all its employees. The sample of managers used in this study represents all the managers at top $(n=22)$, middle $(n=$ $140)$ and lower $(n=287)$ levels. Their relative position was determined by their job levels as specified by the Peromones job evaluation system. Top management consisted of the top three levels and included senior and divisional managers. Middle management in this institution consisted of branch managers and other staff managers on the same Peromones level. Lower management represented the first line supervisors in the bank.

\section{Measurements}

The distribution of influence among the levels of leadership was measured by using a self report questionnaire. A Likert-type of scale was used to assess individual's perception of the extent of their influence over the three domains, described by Moch, et al. (1983). These domains include: influence over work activities, influence over resource allocation, and influence over coordination of activities.

The construction and validation of the measures of the distribution of influence is described elsewhere. (See Moch, et al., 1983). The authors conclude that the questionnaire demonstrated satisfactory convergent and discrimination validity between the domains.

Items included in the influence over work activities assess the respondent's perception of the influence he exerts over how he performs his job. This includes aspects such as problem solving, freedom to change procedures, and extent of decision making.

Influence over resource allocation includes items concerning the allocation, movement, and dismissal of personnel.

Influence over coordination assesses the extent to which respondents settle disagreements among people in their work group, divide the work among members, and reprimand subordinates reporting to them.

\section{Procedure}

The data were collected by means of the questionnaire described above and analysed by using the Statistical Analysis System (SAS). The following procedures were used: analysis of variance and covariance as well as Scheffe's test to identify significant differences between group mean scores. 


\section{Rosults}

The results shown in Table 1 indicate that the differences between groups in respect of the perceived distribution of influence and leadership positions are significant $(P<$ 0,01 ).

The results obtained are supported by Hall (1982), who has stated that leadership at the top is very different from the type of leadership exercised at the lower levels. Research by Tannenbaum \& Katz (1957) and Tannenbaum (1961) has also shown that significant differences exist. Peabody (1962) and French \& Raven (1959) have demonstrated that influence is perceived differently by the recipients of power. The distribution of influence as reflected in this study conforms to previous findings.

Scheffe's test was employed to test the propositions that a specific distribution of influence domain is associated with a particular hierarchical level. This test indicates which means differ significantly $(P<0,05)$ from each other.

Table 1 Analysis of variance of the distribution of influence

\begin{tabular}{lcr}
\hline Influence domain & $d f$ & $F$ \\
\hline Work activities & 2 & $10,19^{\circ}$ \\
Resource allocation & 2 & $33,91^{\circ}$ \\
Coordination & 2 & $7,89^{\circ}$ \\
\hline$P<0,01$ & &
\end{tabular}

The results of Scheffe's test are set out in Tables 2-4.

From Table 2 it is clear that the perceived influence over work activities is highest for the top leadership structure and decreases down the hierarchy. Scheffe's test indicates that these differences are significant. The first proposition stated above may be accepted concerning the distribution of influence over work activities and leadership.

Table 2 The relationship between patterns of leadership and influence over work activities

\begin{tabular}{lrcc}
\hline Hierarchical level & \multicolumn{1}{c}{$n$} & $x$ & Difference \\
\hline Top & 22 & 4,11 & A \\
Middle & 140 & 3,61 & B $^{-}$ \\
Lower & 287 & 3,48 & B $^{\text {n }}$
\end{tabular}

- Groups with the same letter are not significantly different

From Table 3, the results show that the top echelons differ significantly from the other hierarchical levels in respect of the distribution of influence over resource allocation. This finding does not support the second proposition that middle management perceive themselves to have the most influence over the allocation of resources.
Table 3 The relationship between patterns of leadership and influence over resource allocation

\begin{tabular}{lrcc}
\hline Hierarchical level & $n$ & $x$ & Difference \\
\hline Top & 22 & 3,73 & A \\
Middle & 140 & 2,47 & B $^{*}$ \\
Lower & 287 & 2,07 & B $^{*}$ \\
\hline
\end{tabular}

- Groups with the same letter are not significantly different

Table 4 The relationship between patterns of leadership and influence over coordination activities

\begin{tabular}{lrcc}
\hline Hierarchical level & $n$ & $x$ & Difference \\
\hline Top & 22 & 4,00 & A \\
Middle & 140 & 3,37 & B $^{*}$ \\
Lower & 287 & 3,16 & B $^{*}$ \\
\hline
\end{tabular}

- Groups with the same letter are not significantly different

Table 4 shows the results of the distribution of coordination influence and leadership. The results indicate that the top echelons perceive themselves to have the most influence over this domain. The third proposition is consequently rejected that the lower levels perceive that they have the most inluence over this domain.

The relative perceptions of the influence across domains are summarized in Figure 2.

From this figure it is clear that the top echelons perceive themselves to exert the most influence over all domains. The difference between the top and lower

\section{Amount of}

influence

5

4

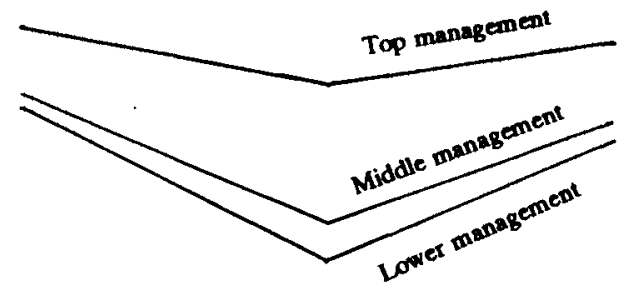

2

1

Work activities Rescurce allocation

Coondination

Flgure 2 Distribution of influence across domains of influence 
levels is significant and more marked than between the middle and lower levels of leadership.

According to research by Moch, et al. (1983) respondents at all levels perceived to exercise more influence over their work activities than over the other domains of influence. This is also evident in this study (refer to Figure 2). In line with Moch, et al. (1983), this domain appears to be highly correlated with the other two domains of influence.

The effect of influence over work activities on the other domains is shown in Table 5.

Table 5 Analysis of variance of the distribution of resource allocation and coordination influence with influence over work activities as covariate

\begin{tabular}{lcc}
\hline Source of variance & $\begin{array}{c}\text { Resource allocation } \\
\text { influence } \\
F\end{array}$ & $\begin{array}{c}\text { Coordination } \\
\text { influence } \\
F\end{array}$ \\
\hline $\begin{array}{l}\text { Job hierarchy } \\
\text { Work activities } \\
\text { influence }\end{array}$ & $22,96^{\star}$ & 1,71 \\
\hline
\end{tabular}

: $P<0,01$

From Table 5 it is evident that there is a significant relationship between the influence over work activities and the other two influence domains. Since the perceived influence over work activities is present at all levels and highly correlated with the other domains it is deemed appropriate to remove its effect through covariance analysis to test the second and third propositions.

The adjusted means for the hierarchical levels and domains of influence over resource allocation and coordination are presented below.

Table 6 Distribution of resource allocation influence adjusted means

\begin{tabular}{lrc}
\hline Hierarchical level & \multicolumn{1}{c}{$n$} & $x$ \\
\hline Top & 22 & $3,33(3,73)^{-}$ \\
Middle & 140 & $2,43(2,47)$ \\
Lower & 287 & $2,12(2,07)$ \\
\hline
\end{tabular}

- Unadjusted mean in parenthesis

Table 7 Distribution of coordination influence adjusted means

\begin{tabular}{lrc}
\hline Hierarchical level & \multicolumn{1}{c}{$n$} & $x$ \\
\hline Top & 22 & $3,54(4,00)^{*}$ \\
Middle & 140 & $3,32(3,37)$ \\
Lower & 287 & $3,21(3, ! 1)$ \\
\hline
\end{tabular}

- Unadjusted mean in parenthesis
From Table 6 the effect of the influence over work activities is evident. The result does not change the finding reported earlier and the second proposition is subsequently rejected.

Table 7 also indicates that the third proposition cannot be accepted.

\section{Discussion}

The purpose of this study was to relate specific domains of influence to particular leadership levels as suggested by Katz \& Kahn's patterns of leadership. From the results presented above it is possible to accept the first proposition although it may be a structural phenomenon rather than a perceptual one.

The results of the remaining distribution of influence domains and the pattern of leadership suggest that other variables such as centralization and formalization, all structural features, as well as the conceptualization of the construct as specified by Moch, et al. (1983) may have played a role in contaminating the results obtained in this study. Furthermore, the results should be treated with caution, as it is a uni-organizational study in which the idiosyncracies of the banking environment, such as strict controls and statutory regulations, may have influenced the findings, thus limiting the generalization of the results.

The effect of centralization is evidenced in the differences between top and lower levels spread across all domains of influence. This suggests a mechanistic orientation which assumes that the top echelons are better equipped to exercise power and authority (Litterer, 1973).

The conclusion may be drawn that if it is possible to relate specific domains of influence to particular hierarchical levels the interaction between structure, organizational climate and individual skills need to be considered. Research needs to be directed at developing a comprehensive model of influence domains and the interaction between these domains needs to be scrutinized. A problem concerning the measures of influence is the failure to specify the construct properly (Moch et al., 1983). Owing to the measurement inadequacy, perceptions of the distribution of influence are not consistent. Moch et al. (1983) note that some individuals respond to questions in terms of a global view, while others respond to specific domains of influence. A single subjective measure needs to be supplemented with objective data regarding the amount of influence exerted.

The domains of influence used in this study may in the light of the above evidence, not reflect the complexities of power and authority, because as organizations survive and develop their power systems become diffuse, complex and ambiguous (Mintzberg, 1984), suggesting that the domains of resource and coordination influence may be redundant and that work activities influence is more pervasive than originally conceptualized.

Furthermore, Luthans (1985) suggests that leadership is a 'black box' concept. To relate the distribution of 
influence to the patterns of management may not be meaningful until more is known about the dynamics of both concepts.

\section{Roferences}

Becker, S. \& Gordon, C. 1966. An entrepreneurial theory of formal organizations. Admin. Sci. Quart. 2, 315-344.

Blake, R.R. \& Mouton, J.S. 1964. The managerial grid. Houston: Gulf. 340p.

Duncan, R.D. 1971. The effects of perceived environmental uncertainty on organizational decision unit structure: a cybernetic model. Unpublished doctoral dissertation. Yale University.

Fiedler, F.E. 1967. A theory of leadership effectiveness. New York: McGraw-Hill. 310p.

French, J.R.P. \& Raven, B.H. 1959. The basis of social power. In: Tosi, H.L. \& Hamner, W.C.(eds.). Organizational behavior and management: a contingency approach. 3rd Ed. New York: Wiley.

Hall, R.H. 1982. Organizations: structure and process. 3rd Ed. Englewood Cliffs, NJ.: Prentice-Hall. 356p.

Hersey, P. \& Blanchard, K. 1982. Management of organizational behavior: utilizing human resources. 4th Ed. Englewood Cliffs, NJ: Prentice Hall. 345p.

House, R.J. 1971. A path-goal theory of leader effectiveness. Admin. Sci. Quart. 16, 321-338.

Katz, D. \& Kahn, R.L. 1978. The social psychology of organizations. 2nd Ed. New York: Wiley. 838p.

Litterer, J.A. 1973. The analysis of organizations. 2nd Ed. New York: Wiley. 757p.

Luthans, F. 1985. Organizational behavior. 4th Ed. New York: McGraw-Hill. 687p.

Mintzberg, H. 1984. Power and organizational life cycles. Acad. Manage. Rev. 9, 207-224.

Moch, M., Cammann, C. \& Cooke, R.A. 1983. Organization structure: measuring the distribution of influence. In: Seashore, S., Lawler, E.E., Mirvis, P.H. \& Cammann, C. (eds.). Assessing organizational change: A guide to methods, measures and practices. New York: Wiley. 563p.

Parsons, T. 1960. Structure and process in modern society. Glencoe, IL: Free Press. 376p.

Peabody, R.L. 1962. Perceptions of organizational authority: a comparative analysis. Admin. Sci. Quart. 6, 463-482.

Scott, W.G., Mitchell, T.R. \& Birnbaum, P.H. 1981. Organization theory: a structural and behavioral analysis. 4th Ed. Homewood, Ill.: Irwin. 356p.

Tannenbaum, A.S. 1961. Control and effectiveness in a voluntary organization. Am. J. Soc. 57, 33-46.

Tannenbaum, A.S. \& Katz, D. 1957. Organizational control structure. Human Rel. 10, 127-140.

Vroom, V.H. 1976. Leadership. In: Dunnette, M.D. (ed.). Handbook of industrial and organizational psychology. Chicago: Rand-McNally. 1527-1551p.

Vroom, V.H. \& Yetton, P.H. 1973. Leadership and decision making. Pittsburgh, Pa.: University of Pittsburgh. 233p. 